\title{
Meta-analysis of factors that affect the utilization efficiency of phosphorus in lactating dairy cows
}

\author{
G. Klop, ${ }^{* 1}$ J. L. Ellis, ${ }^{*}$ A. Bannink,† E. Kebreab,‡ J. France,§ and J. Dijkstra* \\ ${ }^{*}$ Animal Nutrition Group, Wageningen University, PO Box 338, 6700 AH Wageningen, the Netherlands \\ †Wageningen UR Livestock Research, PO Box 65, 8200 AB Lelystad, the Netherlands \\ łDepartment of Animal Science, University of California, 2111 Meyer Hall, One Shields Ave., Davis 95616 \\ §Centre for Nutrition Modelling, Department of Animal and Poultry Science, University of Guelph, Guelph, ON N1G 2W1, Canada
}

\begin{abstract}
A meta-analysis investigation based on literature data was conducted to estimate the effect size of nutritional and animal factors on phosphorus $(\mathrm{P})$ excretion in feces and concentrations of $\mathrm{P}$ in milk. Two data sets were created for statistical analysis: One to derive prediction equations for $\mathrm{P}$ in feces (25 studies; 130 treatments) and another for P in milk (19 studies; 94 treatments). Prediction equations were derived using mixed model regression analysis with a random effect for study, and equations were evaluated based on values for Bayesian information criterion (BIC), root mean square prediction error (RMSPE), and concordance correlation coefficient (CCC) statistics. In terms of RMSPE and CCC values, fecal $\mathrm{P}$ excretion was best predicted by $\mathrm{P}$ intake, where $\mathrm{P}$ in feces $(\mathrm{g} / \mathrm{d})=-3.8( \pm 3.45)+$ $0.64( \pm 0.038) \times \mathrm{P}$ intake $(\mathrm{g} / \mathrm{d})$ (RMSPE: $18.3 \%$, CCC: $0.869)$. However, significant effects of crude protein $[\mathrm{g} /$ $\mathrm{kg}$ of dry matter $(\mathrm{DM})]$, neutral detergent fiber $(\mathrm{g} / \mathrm{kg}$ of DM), and milk yield $(\mathrm{kg} / \mathrm{d})$ on fecal $\mathrm{P}$ excretion were also found. Despite a lack of improvement in terms of RMSPE and CCC values, these parameters may still explain part of the variation in fecal $\mathrm{P}$ excretion. For milk $\mathrm{P}$, expressed as a fraction of $\mathrm{P}$ intake, the following equation had the highest $\mathrm{CCC}$ and the lowest RMSPE value: $\mathrm{P}$ in milk as a fraction of $\mathrm{P}$ intake $(\mathrm{g} / \mathrm{g})$ $=0.42( \pm 0.065)+0.23( \pm 0.018) \times$ feed efficiency (i.e., fat- and protein-corrected milk yield/dry matter intake) $-0.11( \pm 0.0199) \times \mathrm{P}$ in feed $(\mathrm{g} / \mathrm{kg}$ of $\mathrm{DM})$ (RMSPE: 19.7\%; CCC: 0.761). Equations derived to predict fecal $\mathrm{P}$ as a fraction of $\mathrm{P}$ intake $(\mathrm{g} / \mathrm{g})$ or milk $\mathrm{P}$ content $(\mathrm{g} /$ $\mathrm{kg}$ ) could not adequately explain the observed variation and did not perform well in terms of RMSPE and CCC values. Examination of the residuals showed that $\mathrm{P}$ balance was a seemingly confounding factor in some of the models. The results presented here can be used to estimate $\mathrm{P}$ in feces and milk based on commonly
\end{abstract}

Received November 1, 2012.

Accepted February 12, 2013.

${ }^{1}$ Corresponding author: geronda.klop@wur.nl measured dietary and milk variables, but could also be used to guide development of mechanistic models on $\mathrm{P}$ metabolism in lactating dairy cattle. Factors to consider in future research and modeling efforts regarding efficiency of $\mathrm{P}$ use include the effects of dietary neutral detergent fiber, crude protein, starch, variation in $\mathrm{P}$ content of milk, and effects of $\mathrm{P}$ resorption from bone and body tissues during early lactation.

Key words: meta-analysis, phosphorus, dairy cow

\section{INTRODUCTION}

Concerns about the environmental burden caused by nutrient leaching from agricultural soils into the environment and the existing or upcoming stringent regulatory measures on nutrient management in intensive animal agriculture (e.g., US Clean Water Act; EU Water Framework Directive) make it imperative to strive for more efficient phosphorus $(\mathrm{P})$ utilization on dairy farms. Improving $\mathrm{P}$ use efficiency in intensive dairy farming would benefit the environment. Moreover, global mineral $\mathrm{P}$ resources are expected to become more scarce and thus more expensive during the coming decades (Cordell et al., 2009).

It is commonly recognized that total $\mathrm{P}$ intake is the major determinant of fecal $\mathrm{P}$ excretion in dairy cattle. Research has shown that a positive relationship exists between P intake and fecal P excretion (Morse et al., 1992; Ekelund et al., 2005; Kebreab et al., 2005), and several short- and long-term studies with dairy cattle indicate that feeding less $\mathrm{P}$ can reduce fecal $\mathrm{P}$ excretion into the environment (Brintrup et al., 1993; Wu et al., 2000; Ferris et al., 2010). However, effects of nutritional factors other than $\mathrm{P}$ intake on efficiency of $\mathrm{P}$ use are less evident from the literature and warrant further investigation. In addition to dietary factors, animal factors including parity (Knowlton et al., 2001), lactation stage (Knowlton and Herbein, 2002; Ekelund et al., 2006), and milk production level (Valk et al., 2002) may contribute to variation in use of dietary $P$, through direct or indirect effects. An additional issue may be variation in the $\mathrm{P}$ content of milk but infor- 
mation related to this variation is scarce ( $\mathrm{Wu}$ et al., 2000). Excretion of $\mathrm{P}$ in urine is quantitatively of minor importance (NRC, 2001).

A quantitative analysis of literature data regarding $\mathrm{P}$ metabolism in ruminants was previously published by Bravo et al. (2003a,b,c). However, out of the 100 studies included in their analysis, only 6 were studies with lactating dairy cows. Moreover, their work was limited to studies published before May 1999 (Bravo et al., 2003a) and a considerable body of work on P metabolism in dairy cattle has been published since that time. The primary aim of this work, therefore, was to perform a meta-analysis on literature data to estimate the effect size of nutritional factors on the efficiency of $\mathrm{P}$ utilization in dairy cattle. In addition, the potential influence of production parameters; for example, milk yield and milk composition, was considered.

\section{MATERIALS AND METHODS}

\section{Database}

Web of Science (Thomson Reuters, New York, NY) was used to search for peer-reviewed publications that reported at least $\mathrm{P}$ intake and $\mathrm{P}$ excretion in feces or milk, in experiments with dairy cows. In addition, the reference lists of relevant review articles and book chapters were systematically checked for useful publications.

Initially, 42 studies, representing 146 treatments, were retained in the database. Animals within treatments were, if reported, described by parity, physiological state, lactation stage, treatment diet composition, DMI, milk production, milk composition and P-balance data. In some studies, treatments were repeatedly fed during different experimental periods and therefore the total number of observations in the initial database was 235. This initial database contained a large number of missing values, as not all variables of interest were reported for each study. From this initial database, 2 subsets of data were created: a subset for $\mathrm{P}$ excretion in feces ( $\mathbf{P F}$ equations) and another subset for $\mathrm{P}$ in milk (PM equations). Observations with missing values for the parameters of interest were excluded from the analysis. The 2 database subsets had 13 studies in common.

Phosphorus in Feces. This database subset comprised data from lactating dairy cows from 25 studies (Martz et al., 1990; Morse et al., 1992; Spiekers et al., 1993; Delaquis and Block, 1995; Khorasani et al., 1997; Knowlton et al., 2001, 2002; Wu et al., 2001, 2003; Knowlton and Herbein, 2002; Guyton et al., 2003; Kebreab et al., 2005; Kincaid et al., 2005; Shore et al., 2005; Wu, 2005; Ekelund et al., 2006; Kamiya et al., 2006a; Knowlton et al., 2007; Dann et al., 2008; Moreira et al., 2009; Myers and Beede, 2009; Taylor et al., 2009; Van Straalen et al., 2009; Herrera et al., 2010; Puggaard et al., 2011) and included 130 treatment means. The response variable of interest was $\mathrm{P}$ excretion in the feces, both in grams per day and as a fraction of $\mathrm{P}$ intake. The available prediction variables in this data set were milk yield $(\mathrm{kg} / \mathrm{d})$, DMI $(\mathrm{kg} / \mathrm{d})$, dietary NDF ( $\mathrm{g} / \mathrm{kg}$ of $\mathrm{DM}), \mathrm{CP}(\mathrm{g} / \mathrm{kg}$ of $\mathrm{DM})$, and $\mathrm{P}$ $(\mathrm{g} / \mathrm{kg}$ of $\mathrm{DM})$, and the database is described in Table 1. The effect of calcium (Ca) content of the diet was never significant in the initial exploratory analyses of the general database, and therefore was not used as a selection criterion during the compilation of this data subset.

Phosphorus in Milk. This database subset contained 94 treatment means from 19 studies (Martz et al., 1990; Spiekers et al., 1993; Delaquis and Block, 1995; Knowlton et al., 2001, 2002; Knowlton and Herbein, 2002; Valk et al., 2002; Guyton et al., 2003; Borucki Castro et al., 2004; Kincaid et al., 2005; Peterson et al., 2005; Roche et al., 2005; Shore et al., 2005; Kamiya et al., 2006b; Odongo et al., 2007; Dann et al., 2008;

Table 1. Descriptive statistics of the fecal $\mathrm{P}$ data subset $(\mathrm{n}=130)$

\begin{tabular}{|c|c|c|c|c|c|c|c|}
\hline Variable & Mean & Median & $\mathrm{SD}$ & Minimum $^{1}$ & Maximum $^{2}$ & Skewness $^{3}$ & Kurtosis $^{4}$ \\
\hline DMI $(\mathrm{kg} / \mathrm{d})$ & 22.0 & 22.2 & 3.52 & 11.3 & 29.0 & -0.29 & -0.27 \\
\hline Dietary CP $(\mathrm{g} / \mathrm{kg}$ of $\mathrm{DM})$ & 169 & 169 & 14.7 & 122 & 213 & 0.45 & 1.77 \\
\hline Dietary $\mathrm{P}(\mathrm{g} / \mathrm{kg}$ of $\mathrm{DM})$ & 4.1 & 3.9 & 0.98 & 1.5 & 6.7 & 0.59 & 0.57 \\
\hline $\mathrm{P}$ intake $(\mathrm{g} / \mathrm{d})$ & 88.3 & 82.0 & 26.93 & 29.4 & 179.7 & 0.86 & 1.15 \\
\hline Fecal P $(\mathrm{g} / \mathrm{d})$ & 53.7 & 49.3 & 21.04 & 15.3 & 118.8 & 0.82 & 0.46 \\
\hline
\end{tabular}

\footnotetext{
${ }^{1}$ Minimum value in the subset database.

${ }^{2}$ Maximum value in the subset database.

${ }^{3}$ The degree of asymmetry of a distribution around its mean, where $0 \pm 2 \times \mathrm{SE}_{\text {skewness }}$ is considered normal. For the fecal $\mathrm{P}$ database, $2 \times$ $\mathrm{SE}_{\text {skewness }}=0.43$.

${ }^{4}$ Indicates the relative peakedness of or flatness of a distribution, where $0 \pm 2 \times \mathrm{SE}_{\text {kurtosis }}$ is considered normal. For the fecal $\mathrm{P}$ database, $2 \times$ $\mathrm{SE}_{\text {kurtosis }}=0.35$.
} 
Table 2. Descriptive statistics of the milk P data subset $(\mathrm{n}=94)$

\begin{tabular}{|c|c|c|c|c|c|c|c|}
\hline Variable & Mean & Median & $\mathrm{SD}$ & Minimum $^{1}$ & Maximum $^{2}$ & Skewness $^{3}$ & Kurtosis $^{4}$ \\
\hline FCM $(\mathrm{kg} / \mathrm{d})$ & 34.7 & 34.0 & 8.28 & 11.1 & 59.2 & 0.17 & 0.76 \\
\hline $\operatorname{FPCM}^{5}(\mathrm{~kg} / \mathrm{d})$ & 34.4 & 34.1 & 7.99 & 11.0 & 56.1 & 0.00 & 0.52 \\
\hline Milk protein $(\%)$ & 3.0 & 3.0 & 0.27 & 2.3 & 3.7 & 0.50 & -0.19 \\
\hline Milk P (g/kg) & 0.89 & 0.89 & 0.09 & 0.66 & 1.10 & -0.14 & -0.32 \\
\hline $\mathrm{DMI}(\mathrm{kg} / \mathrm{d})$ & 21.8 & 22.3 & 4.13 & 10.9 & 29.0 & -0.57 & -0.05 \\
\hline Milk $\mathrm{P} / \mathrm{P}$ intake $(\mathrm{g} / \mathrm{g})$ & 0.42 & 0.42 & 0.11 & 0.21 & 0.84 & 0.56 & 0.72 \\
\hline Feed efficiency ${ }^{6}$ & 1.6 & 1.5 & 0.37 & 1.0 & 3.0 & 1.71 & 3.39 \\
\hline
\end{tabular}

${ }^{1}$ Minimum value in the subset database.

${ }^{2}$ Maximum value in the subset database.

${ }^{3}$ The degree of asymmetry of a distribution around its mean, where $0 \pm 2 \times \mathrm{SE}_{\text {skewness }}$ is considered normal. For the milk $\mathrm{P}$ database, $2 \times$ $\mathrm{SE}_{\text {skewness }}=0.51$.

${ }^{4}$ Indicates the relative peakedness of or flatness of a distribution, where $0 \pm 2 \times \mathrm{SE}_{\mathrm{kurtosis}}$ is considered normal. For the milk $\mathrm{P}$ database, $2 \times$ $\mathrm{SE}_{\text {kurtosis }}=0.41$.

${ }^{5}$ Fat- and protein-corrected milk.

${ }^{6}$ Calculated as FPCM yield $(\mathrm{kg} / \mathrm{d}) / \mathrm{DMI}(\mathrm{kg} / \mathrm{d})$.

Myers and Beede, 2009; Taylor et al., 2009; Puggaard et al., 2011). The response variables of interest were milk $\mathrm{P}$ in grams per day, grams per kilogram of milk, or as a fraction of $\mathrm{P}$ intake. All treatment means in this subset contained information on milk yield $(\mathrm{kg} / \mathrm{d})$, milk fat and milk protein contents, DMI, and dietary $\mathrm{P}(\mathrm{g} / \mathrm{kg}$ of DM). Fat-corrected milk yield and fat- and protein-corrected milk yield (FPCM) were calculated for each treatment according to the respective formulas provided by CVB $(2008): \mathrm{FCM}=(0.4+0.15 \times$ fat $\%)$ $\times$ milk yield $(\mathrm{kg} / \mathrm{d})$ and $\mathrm{FPCM}=(0.337+0.116 \times$ fat $\%+0.06 \times$ protein $\%) \times$ milk yield $(\mathrm{kg} / \mathrm{d})$. Feed efficiency was calculated as kilograms of FPCM yield per kilogram of DMI. The data set is described in Table 2.

\section{Statistical Analysis}

In Tables 1 and 2, the skewness values for the respective data subsets indicate the degree of asymmetry of a distribution around its mean, where $0 \pm 2 \times$ $\mathrm{SE}_{\text {skewness }}$ is considered normal. The $\mathrm{SE}_{\text {skewness }}$ is calculated as $\sqrt{ }(6 / \mathrm{n})$ and was 0.215 for the fecal $\mathrm{P}$ subset and 0.253 for the milk $\mathrm{P}$ subset. The kurtosis values can be used to indicate the relative peakedness or flatness of a distribution, where $0 \pm 2 \times \mathrm{SE}_{\text {kurtosis }}$ is considered normal. The $\mathrm{SE}_{\text {kurtosis }}$ is calculated as $\sqrt{ }(4 / \mathrm{n})$ and was 0.175 and 0.206 for the fecal $\mathrm{P}$ and milk $\mathrm{P}$ subset, respectively.

Model Development. Before creation of the 2 data subsets, statistical analyses using PROC MIXED and PROC REG MAXR (SAS Institute Inc., Cary, NC) were performed to explore patterns in the data and to determine the most important available variables for inclusion in the statistical analysis.

For both data subsets, main effects and combined effects of available explanatory variables were analyzed for inclusion in linear regression models using PROC MIXED (SAS Institute Inc.). Mixed model analysis was chosen because the data were compiled from multiple studies, making it necessary to consider analyzing not only fixed effects of the dependent variables but also the random effect of study (St-Pierre, 2001). The random effect of study accounts for differences between studies such as physiological status of animals, experimental design, and methods and techniques used to collect the data. The full statistical model is written as

$$
Y_{i j}=B_{0}+B_{1} X_{i j}+s_{i}+b_{i} X_{i j}+e_{i j},
$$

where $Y_{i j}$ is the dependent variable (ith study $1, \ldots$, 25 , jth treatment $1, \ldots, 130$; and ith study $1, \ldots, 19$, $j$ th treatment $1, \ldots, 94$ for the fecal $\mathrm{P}$ and milk $\mathrm{P}$ database subsets, respectively) and $X_{i j}$ is the value of the continuous prediction variable. The overall intercept $\left(B_{0}\right)$ and the overall regression coefficient of $Y$ on $X$ $\left(B_{1}\right)$ across all studies comprise the fixed effects part of the model. The random effect of the $i$ th study on the overall intercept $\left(s_{i}\right)$ and the random effect of study $i$ on the regression coefficient of $Y$ on $X\left(b_{i}\right)$ comprise the random effects part of the model, and $e_{i j}$ represents the residual error term.

To account for variation in precision across studies, the inverse of the squared standard error of each treatment mean was used as a factor in the WEIGHT 
statement of the model (St-Pierre, 2001). Preferably an unstructured (UN) variance-covariance structure was fitted, as this allows every term in the variancecovariance matrix to be different. However, using this structure requires estimation of a large number of variance and covariance parameters, which may result in over-parameterization and nonconvergence of the model. In cases of nonconvergence, effects were removed stepwise from the random statement, or a compound symmetry (CS) variance-covariance structure was fitted, which is based on the assumption that the covariance between studies is equal for all studies. Because accurate estimation of variance and covariance requires a large number of observations, more liberal $P$-values than $P<0.05$ were used to test effects included in the random statement (St-Pierre, 2001; Sauvant et al., 2008). In all cases, the Bayesian information criterion (BIC) was used as the statistical criterion to indicate the goodness of model fit, where lower values indicate a better fit (SAS Institute Inc.). Parameter estimates for fixed effects were tested against a significance level of $P<0.05$.

Model Evaluation. The models derived from this study were evaluated using mean square prediction error (MSPE) (Bibby and Toutenburg, 1977) against the developmental database. The MSPE was calculated as

$$
M S P E=\sum_{i=1}^{n}\left(O_{i}-P_{i}\right)^{2} / n,
$$

where $n$ is the total number of observations, $O_{i}$ is the observed value, and $P_{i}$ is the predicted value. The square root of the MSPE (RMSPE), expressed as a fraction of the observed mean, provides an estimate of the overall prediction error. The RMSPE was decomposed into error resulting from overall bias (ECT), error resulting from deviation of the regression slope from unity (ER), and random error (ED). The concordance correlation coefficient (CCC; Lin, 1989) was used as a second model evaluation tool, and is calculated as

$$
\mathrm{CCC}=R \times C_{b},
$$

where $R$ is the Pearson correlation coefficient and $C_{b}$ is the bias correction factor. The $R$ value provides a measure of precision, whereas $C_{b}$ is indicative for the accuracy of the model. The measures $v$ (scale shift) and $\mu$ (location shift) are used to calculate $C_{b}$, where a change in $v$ indicates differences in standard deviation between predicted and observed values. A negative value of $\mu$ indicates overprediction, whereas a positive value indicates underprediction (see Ellis et al., 2010, for discussion on MSPE vs. CCC as evaluation tools).
Residual Analysis. The residuals (predicted observed) were visually examined for any patterns, as well as for any potentially confounding factors. Residuals were tested for normality using the UNIVARIATE procedure in SAS, and residual slopes were tested for significant difference from zero, an indication of heteroscedasticity.

\section{RESULTS AND DISCUSSION}

\section{Fecal $P$}

Linear regression equations derived for the prediction of total fecal $\mathrm{P}$ excretion $(\mathrm{g} / \mathrm{d}$ and $\mathrm{g} / \mathrm{g}$ of $\mathrm{P}$ intake) are listed in Table 3. Model evaluation based on RMSPE, CCC, and BIC is shown in Table 4. In this study, BIC was used as a statistical criterion to evaluate model fit, because it imposes a larger penalty for over-parameterization compared with the Akaike information criterion. However, the Akaike information criterion and BIC values of the models derived in this study were similar.

Fecal $\boldsymbol{P}(\boldsymbol{g} / \boldsymbol{d})$. The use of DMI as the only prediction variable for fecal $\mathrm{P}$ excretion $(\mathrm{g} / \mathrm{d})$ resulted in a prediction equation that was neither accurate nor precise. Models that include DMI plus dietary $\mathrm{P}(\mathrm{g} / \mathrm{kg}$ of $\mathrm{DM}$; PF2) or P intake (g/d) alone (PF3) as prediction variables resulted in much better prediction of fecal $\mathrm{P}$ excretion (Table 4). The positive parameter estimates for DMI and dietary $\mathrm{P}(\mathrm{g} / \mathrm{kg}$ of $\mathrm{DM})$ indicate a positive relationship between $\mathrm{P}$ intake and $\mathrm{P}$ excretion in the feces, which is in line with general expectations. The slope estimate for $\mathrm{P}$ intake $(\mathrm{g} / \mathrm{d})$ in equation PF3 $(0.64 \pm 0.038)$ is similar to the estimated effect size of $\mathrm{P}$ intake $(0.63 \pm 0.046)$ reported by Weiss and Wyatt (2004). Despite limited within-study variation in the developmental database, parameter estimates for the effects of $\mathrm{CP}(\mathrm{g} / \mathrm{kg}$ of $\mathrm{DM})$ and $\mathrm{NDF}(\mathrm{g} / \mathrm{kg}$ of $\mathrm{DM})$ were significant, although addition of these variables to a prediction equation that already included DMI and dietary $\mathrm{P}$ ( $\mathrm{g} / \mathrm{kg}$ of $\mathrm{DM}$; PF4 to PF6) did not always result in improved values for RMSPE and CCC (Table 4). However, equation PF6 [DMI $(\mathrm{kg} / \mathrm{d}), \mathrm{P}$ (g/ $\mathrm{kg}$ of $\mathrm{DM}), \mathrm{CP}(\mathrm{g} / \mathrm{kg}$ of DM), and NDF (g/kg of DM)] had a lower BIC value than equation PF2 [DMI $(\mathrm{kg} / \mathrm{d})$ and $\mathrm{P}(\mathrm{g} / \mathrm{kg}$ of DM) $]$. Root MSPE and CCC statistics evaluate only the fixed effects of the model, whereas in SAS PROC MIXED, model fit (e.g., evident in the BIC value) is evaluated based on both fixed and random effects. As the MIXED procedure considers the regression relationship within study, whereas dietary NDF and $\mathrm{CP}$ did not vary substantially within study, the capture of the relationship between $\mathrm{CP}$ or NDF and 


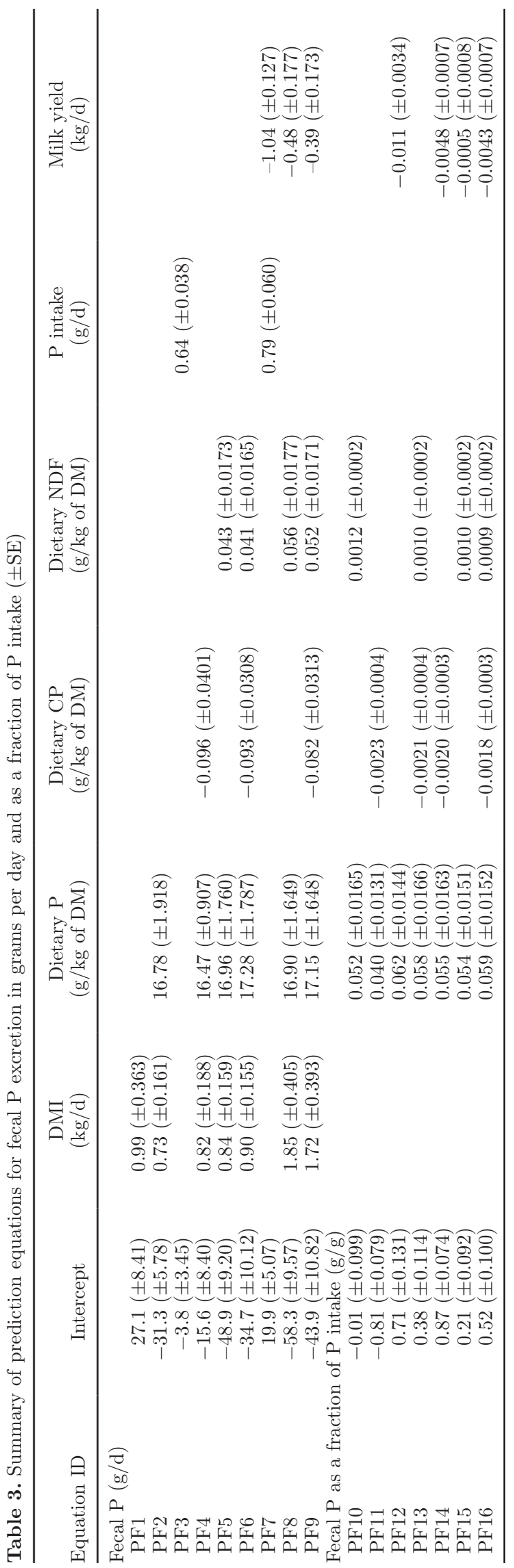

fecal $\mathrm{P}$ excretion is challenging. Nevertheless, the significant estimates and, in some cases, lower BIC values indicate that these parameters may still be important in explaining part of the variation in fecal $\mathrm{P}$ excretion. Although in the current database, we found no correlation between dietary levels of $\mathrm{CP}$ and $\mathrm{P}(\mathrm{r}=0.07)$, dietary CP level may be confounded with the source of P. Variation exists in absorption efficiency of different $\mathrm{P}$ sources, but if $\mathrm{P}$ supply is adequate, such variation is of less relevance to $\mathrm{P}$ efficiency compared with diets that supply marginal amounts of $\mathrm{P}$.

The estimate for the effect of dietary NDF was positive in all equations. A biological explanation for this result could be that absorbed P in excess of the animal's requirements is extensively recycled through saliva. It has been suggested that dietary NDF content increases salivary $\mathrm{P}$ secretion as a result of increased saliva flow caused by increased chewing (Khorasani et al., 1997; Wu et al., 2003), but that the effect of NDF content on salivary $\mathrm{P}$ secretion would likely be less at lower levels of dietary P (Wu et al., 2003). At low P intake, the animal's priority is rumen function at the expense of bone or salivary P (Puggaard et al., 2011). High dietary NDF levels also likely coincide with low levels of dietary starch and, in general, may be associated with a lower availability of fermentable substrate for microbes in the rumen, thus reducing $\mathrm{P}$ uptake by the ruminal microbes. Kebreab et al. (2005) showed that type and density of energy in the feed have a significant effect on $\mathrm{P}$ excretion in cattle. In comparing 2 experiments with high and low energy intakes, they found that $\mathrm{P}$ efficiency improved significantly in cows fed a higher energy diet (consuming at least an extra $30 \mathrm{MJ} / \mathrm{d}$ ). Increased P efficiency could be due to higher P uptake by microbes in the rumen and greater conversion of dietary $\mathrm{P}$ to milk production and body growth. Parameter estimates for dietary $\mathrm{CP}(\mathrm{g} / \mathrm{kg}$ of $\mathrm{DM})$ were always negative, indicating lower $\mathrm{P}$ excretion in the feces at higher CP content in the diet. During early lactation in particular, milk production may increase with increasing dietary CP content (Kalscheur et al., 1999; Law et al., 2009). This would lead to higher $\mathrm{P}$ requirements for milk production and could thus reduce fecal excretion of $\mathrm{P}$. The negative association between dietary $\mathrm{CP}$ content and $\mathrm{P}$ excretion in feces is of particular interest in view of efforts to reduce $\mathrm{N}$ excretion in dairy cattle. Recently, dietary CP content has tended to be reduced in various intensive dairy production systems (e.g., Bannink et al., 2011). This decrease in CP content has already been shown to increase enteric methane production in cattle (Dijkstra et al., 2011), and the present findings indicate that $\mathrm{CP}$ reductions could also increase $\mathrm{P}$ excretion in feces. In equations that already included the effects of DMI and P (g/ $\mathrm{kg}$ of DM), or the effects of 
Table 4. Evaluation of prediction equations for fecal $\mathrm{P}$ excretion in grams per day and as a fraction of $\mathrm{P}$ intake

\begin{tabular}{|c|c|c|c|c|c|c|c|c|c|c|c|}
\hline Equation ID & Prediction variables & $\underset{(\%)^{1}}{\operatorname{RMSPE}}$ & $\begin{array}{l}\mathrm{ECT} \\
(\%)^{2}\end{array}$ & $\begin{array}{l}\mathrm{ER} \\
(\%)^{3}\end{array}$ & $\begin{array}{l}\mathrm{ED} \\
(\%)^{4}\end{array}$ & $\mathrm{CCC}^{5}$ & $R^{6}$ & $C_{b}^{7}$ & $v^{8}$ & $\mu^{9}$ & $\mathrm{BIC}^{10}$ \\
\hline \multicolumn{12}{|l|}{ Fecal P (g/d) } \\
\hline PF1 & DMI $(\mathrm{kg} / \mathrm{d})$ & 38.0 & 5.3 & 5.9 & 88.9 & 0.124 & 0.402 & 0.309 & 6.007 & 0.546 & $1,063.3$ \\
\hline PF2 & DMI $(\mathrm{kg} / \mathrm{d}), \mathrm{P}(\mathrm{g} / \mathrm{kg}$ of $\mathrm{DM})$ & 21.3 & 0.4 & 0.7 & 98.9 & 0.819 & 0.841 & 0.974 & 1.255 & 0.039 & 871.0 \\
\hline PF3 & $\mathrm{P}$ intake $(\mathrm{g} / \mathrm{d})$ & 18.3 & 1.1 & 2.3 & 96.6 & 0.869 & 0.888 & 0.979 & 1.224 & 0.054 & 922.7 \\
\hline PF4 & $\begin{array}{l}\mathrm{DMI}(\mathrm{kg} / \mathrm{d}), \mathrm{P}(\mathrm{g} / \mathrm{kg} \text { of } \mathrm{DM}), \mathrm{CP} \\
(\mathrm{g} / \mathrm{kg} \text { of } \mathrm{DM})\end{array}$ & 21.3 & 0.2 & 1.1 & 98.8 & 0.815 & 0.840 & 0.971 & 1.277 & 0.025 & 904.2 \\
\hline PF5 & $\begin{array}{l}\mathrm{DMI}(\mathrm{kg} / \mathrm{d}), \mathrm{P}(\mathrm{g} / \mathrm{kg} \text { of } \mathrm{DM}), \mathrm{NDF} \\
(\mathrm{g} / \mathrm{kg} \text { of } \mathrm{DM})\end{array}$ & 22.4 & 0.3 & 0.2 & 99.5 & 0.800 & 0.821 & 0.974 & 1.255 & 0.036 & 871.3 \\
\hline PF6 & $\begin{array}{l}\mathrm{DMI}(\mathrm{kg} / \mathrm{d}), \mathrm{P}(\mathrm{g} / \mathrm{kg} \text { of } \mathrm{DM}), \mathrm{CP} \\
(\mathrm{g} / \mathrm{kg} \text { of } \mathrm{DM}), \mathrm{NDF}(\mathrm{g} / \mathrm{kg} \text { of } \mathrm{DM})\end{array}$ & 22.4 & 0.1 & 0.0 & 99.9 & 0.802 & 0.820 & 0.978 & 1.235 & 0.015 & 866.8 \\
\hline PF7 & $\mathrm{P}$ intake $(\mathrm{g} / \mathrm{d})$, milk yield $(\mathrm{kg} / \mathrm{d})$ & 21.0 & 0.1 & 2.7 & 97.2 & 0.845 & 0.847 & 0.998 & 1.068 & 0.016 & 857.9 \\
\hline PF8 & $\begin{array}{l}\mathrm{DMI}(\mathrm{kg} / \mathrm{d}), \mathrm{P}(\mathrm{g} / \mathrm{kg} \text { of } \mathrm{DM}), \mathrm{NDF} \\
(\mathrm{g} / \mathrm{kg} \text { of } \mathrm{DM}), \text { milk yield }(\mathrm{kg} / \mathrm{d})\end{array}$ & 23.1 & 0.2 & 0.0 & 99.8 & 0.791 & 0.807 & 0.980 & 1.219 & 0.027 & 865.5 \\
\hline PF9 & $\begin{array}{l}\mathrm{DMI}(\mathrm{kg} / \mathrm{d}), \mathrm{P}(\mathrm{g} / \mathrm{kg} \text { of } \mathrm{DM}), \mathrm{CP} \\
(\mathrm{g} / \mathrm{kg} \text { of } \mathrm{DM}), \mathrm{NDF}(\mathrm{g} / \mathrm{kg} \text { of } \mathrm{DM}) \\
\text { milk yield }(\mathrm{kg} / \mathrm{d})\end{array}$ & 22.8 & 0.0 & 0.0 & 99.9 & 0.797 & 0.812 & 0.981 & 1.216 & 0.014 & 863.4 \\
\hline \multicolumn{12}{|c|}{ Fecal $\mathrm{P}$ as a fraction of $\mathrm{P}$ intake $(\mathrm{g} / \mathrm{g})$} \\
\hline PF10 & $\mathrm{P}(\mathrm{g} / \mathrm{kg}$ of DM), NDF (g/kg of DM) & 19.3 & 0.3 & 14.7 & 85.1 & 0.238 & 0.260 & 0.917 & 1.515 & 0.072 & -246.5 \\
\hline PF11 & $\mathrm{P}(\mathrm{g} / \mathrm{kg}$ of $\mathrm{DM}), \mathrm{CP}(\mathrm{g} / \mathrm{kg}$ of $\mathrm{DM})$ & 18.7 & 0.1 & 6.2 & 93.7 & 0.145 & 0.195 & 0.745 & 2.237 & 0.041 & -249.6 \\
\hline PF12 & $\mathrm{P}(\mathrm{g} / \mathrm{kg}$ of $\mathrm{DM})$, milk yield $(\mathrm{kg} / \mathrm{d})$ & 22.8 & 3.3 & 37.3 & 59.7 & 0.290 & 0.297 & 0.976 & 0.954 & 0.218 & -286.2 \\
\hline PF13 & $\begin{array}{l}\mathrm{P}(\mathrm{g} / \mathrm{kg} \text { of } \mathrm{DM}), \mathrm{CP}(\mathrm{g} / \mathrm{kg} \text { of DM }), \mathrm{NDF} \\
(\mathrm{g} / \mathrm{kg} \text { of } \mathrm{DM})\end{array}$ & 19.6 & 0.1 & 16.6 & 83.4 & 0.222 & 0.240 & 0.925 & 1.488 & 0.049 & -262.2 \\
\hline PF14 & $\begin{array}{l}\mathrm{P}(\mathrm{g} / \mathrm{kg} \text { of } \mathrm{DM}), \mathrm{CP}(\mathrm{g} / \mathrm{kg} \text { of } \mathrm{DM}) \\
\text { milk yield }(\mathrm{kg} / \mathrm{d})\end{array}$ & 19.0 & 0.2 & 13.5 & 86.4 & 0.266 & 0.289 & 0.921 & 1.502 & 0.062 & -277.7 \\
\hline PF15 & $\begin{array}{l}\mathrm{P}(\mathrm{g} / \mathrm{kg} \text { of } \mathrm{DM}), \mathrm{NDF}(\mathrm{g} / \mathrm{kg} \text { of } \mathrm{DM}) \\
\text { milk yield }(\mathrm{kg} / \mathrm{d})\end{array}$ & 21.5 & 0.3 & 31.0 & 68.9 & 0.258 & 0.260 & 0.993 & 1.104 & 0.067 & -271.4 \\
\hline PF16 & $\begin{array}{l}\mathrm{P}(\mathrm{g} / \mathrm{kg} \text { of DM }), \mathrm{CP}(\mathrm{g} / \mathrm{kg} \text { of } \mathrm{DM}), \mathrm{NDF} \\
(\mathrm{g} / \mathrm{kg} \text { of } \mathrm{DM}), \text { milk yield }(\mathrm{kg} / \mathrm{d})\end{array}$ & 21.0 & 0.2 & 27.9 & 72.2 & 0.252 & 0.256 & 0.986 & 1.171 & 0.052 & -286.5 \\
\hline
\end{tabular}

ᄃ. $\quad{ }^{1}$ Root mean square prediction error expressed as a percentage of the observed mean.

글 ${ }^{2}$ Error resulting from overall bias, as a percentage of total MSPE.

D ${ }^{3}$ Error resulting from deviation of the regression slope from unity, as a percentage of total MSPE.

${ }^{4}$ Random error, as a percentage of total MSPE.

D. $\quad{ }^{5}$ Concordance correlation coefficient, where $\mathrm{CCC}=R \times C_{b}$.

$\gtrless \quad{ }^{6}$ Pearson correlation coefficient.

กิ. $\quad{ }^{7}$ Bias correction factor.

${ }^{8}$ Scale shift.

${ }^{9}$ Location shift.

을 ${ }^{10}$ Bayesian information criterion for goodness of model fit. 
DMI, P ( $\mathrm{g} / \mathrm{kg}$ of DM), and CP ( $\mathrm{g} / \mathrm{kg}$ of DM), the effect of milk yield on fecal $\mathrm{P}$ excretion was only significant if the effect of NDF $(\mathrm{g} / \mathrm{kg}$ of DM) was also included in the equation (PF8; Table 3). The estimates for the effect of milk yield on fecal $\mathrm{P}$ excretion were negative, which corresponds to the findings of Valk et al. (2002), who concluded that higher milk production within a dietary $\mathrm{P}$ level results in relatively less fecal $\mathrm{P}$ excretion, because more $\mathrm{P}$ will be channeled into milk. Nennich et al. (2005) reported a positive relationship between milk yield and total $\mathrm{P}$ excretion, but the average dietary $\mathrm{P}$ content in their database was $4.4 \mathrm{~g} / \mathrm{kg}$ of DM, which is more than needed to meet animal requirements.

The residual (observed - predicted) versus predicted plots for some of the best performing equations are presented in Figure 1. No obvious patterns are evident in the plots, despite a seemingly mild fan shape for PF6, which is likely the result of fewer data points at lower predicted values. However, to see if any improvements could be made, a Box-Cox transformation procedure (Box and Cox, 1964) was tested in the MIXED procedure of SAS to define the optimal transformation of the dependent variable. Data transformation improved the performance of the models in terms of RMSPE and CCC values (results not shown), but the overall picture remained the same: $\mathrm{P}$ intake being the major determinant of $\mathrm{P}$ excretion in feces and dietary NDF and $\mathrm{CP}$ having significant estimates, but no added value in terms of RMSPE and CCC when including them in an equation that already has DMI and P (g/ $\mathrm{kg}$ of $\mathrm{DM}$ ) as prediction variables. Moreover, the shape of the residual plots did not change substantially after data transformation. Because of increased ease of interpretation of the linear equations compared with transformed equations, and due to concern over producing an over-complicated equation given the quality of the developmental data, the linear equations based on the untransformed data are reported here, although it is acknowledged that biological phenomena are often nonlinear, and empirical equations are generally only applicable within the range of data included in the developmental database.

Plotting the residuals for fecal $\mathrm{P}(\mathrm{g} / \mathrm{d})$ against $\mathrm{P}$ balance data (available for 14 studies in the fecal $\mathrm{P}$ data set; $\mathrm{n}=81$ ) shows that $\mathrm{P}$ balance may have a confounding effect, in particular for equation PF7 $[\mathrm{P}$ intake $(\mathrm{g} / \mathrm{d})$ and milk yield $(\mathrm{kg} / \mathrm{d})]$, with underprediction of fecal $\mathrm{P}$ excretion in the case of negative $\mathrm{P}$ balance (Figure 1). Negative $\mathrm{P}$ balance is a naturally occurring phenomenon during early lactation. Ekelund et al. (2006) reported that lowering dietary $\mathrm{P}$ with the aim of benefiting from naturally occurring bone resorption for $\mathrm{P}$ supply in early lactation did not result in increased bone resorption compared with cows fed higher amounts of P. Reduction of the dietary P concentration during early lactation could thus be a viable strategy to reduce fecal $\mathrm{P}$ excretion during this period.

For most of the studies in our database, no information was available on dietary starch content. The positive estimate for dietary NDF when predicting fecal P excretion could imply an opposite effect of starch on fecal $\mathrm{P}$ excretion given the generally negative correlation between the dietary NDF fraction and the fraction of NFC in diets of dairy cattle (Armentano and Pereira, 1997; NRC, 2001). Diets low in NDF and high in starch will most likely have a higher DM digestibility, with the major exception of situations with low rumen $\mathrm{pH}$ caused by high levels of fermentable carbohydrates, resulting in reduction of NDF degradation in the rumen (Dijkstra et al., 2012). The negative relationship between DM digestibility and $\mathrm{P}$ excretion in feces reported by Weiss and Wyatt (2004) support our data in this respect. However, not the absolute amount, but rather the digestive characteristics of starch may affect the efficiency of utilization of $\mathrm{P}$ in terms of total $\mathrm{P}$ excretion $(\mathrm{g} / \mathrm{d})$ and $\mathrm{P}$ excretion per gram of milk $\mathrm{P}$ produced (Guyton et al., 2003; Kebreab et al., 2005). Guyton et al. (2003) studied the effect of 2 dietary P levels and 2 starch sources on fecal P excretion. Values of 1.8 and $2.6 \mathrm{~g}$ of fecal $\mathrm{P} / \mathrm{g}$ of milk $\mathrm{P}$ were reported for low dietary $\mathrm{P}$ and high dietary $\mathrm{P}$, respectively. Similarly, the least digestible and most digestible starch source resulted in excretion values of 2.4 and $2.0 \mathrm{~g}$ of fecal P/g of milk $\mathrm{P}$, respectively. These results indicate that the reduction in $\mathrm{P}$ excretion could mainly be attributed to lower $\mathrm{P}$ intake. The effect of starch digestibility on fecal $\mathrm{P}$ excretion was reflected in a significantly higher feed efficiency of cows receiving the high digestible starch source in terms of kilograms of milk produced per kilogram of DMI. However, it is more appropriate to express feed efficiency of dairy cows as kilograms of FCM or FPCM per kilogram of DMI (Beever and Doyle, 2007). Milk fat production differed significantly in the study of Guyton et al. (2003), and feed efficiency based on FCM did not show this pronounced difference.

Fecal $P$ as a Fraction of $P$ Intake $(g / g)$. Several prediction equations with significant parameter estimates were derived for the prediction of fecal $\mathrm{P}$ excretion expressed as a fraction of $\mathrm{P}$ intake (Table 3 ). Similar to the equations for fecal $\mathrm{P}(\mathrm{g} / \mathrm{d})$, estimates for the effects of $\mathrm{CP}$ and milk yield were negative in all equations, and estimates for the effects of dietary $\mathrm{P}$ $(\mathrm{g} / \mathrm{kg}$ of $\mathrm{DM})$ and $\mathrm{NDF}(\mathrm{g} / \mathrm{kg}$ of $\mathrm{DM})$ were positive in all equations. The effect of DMI on fecal $\mathrm{P}$ excretion as a fraction of $\mathrm{P}$ intake was not significant. The prediction equation with dietary $\mathrm{P}$ content and milk yield (PF12) was among the best in terms of CCC and BIC values. When $\mathrm{NDF}$ and $\mathrm{CP}$ were added (PF16), their 

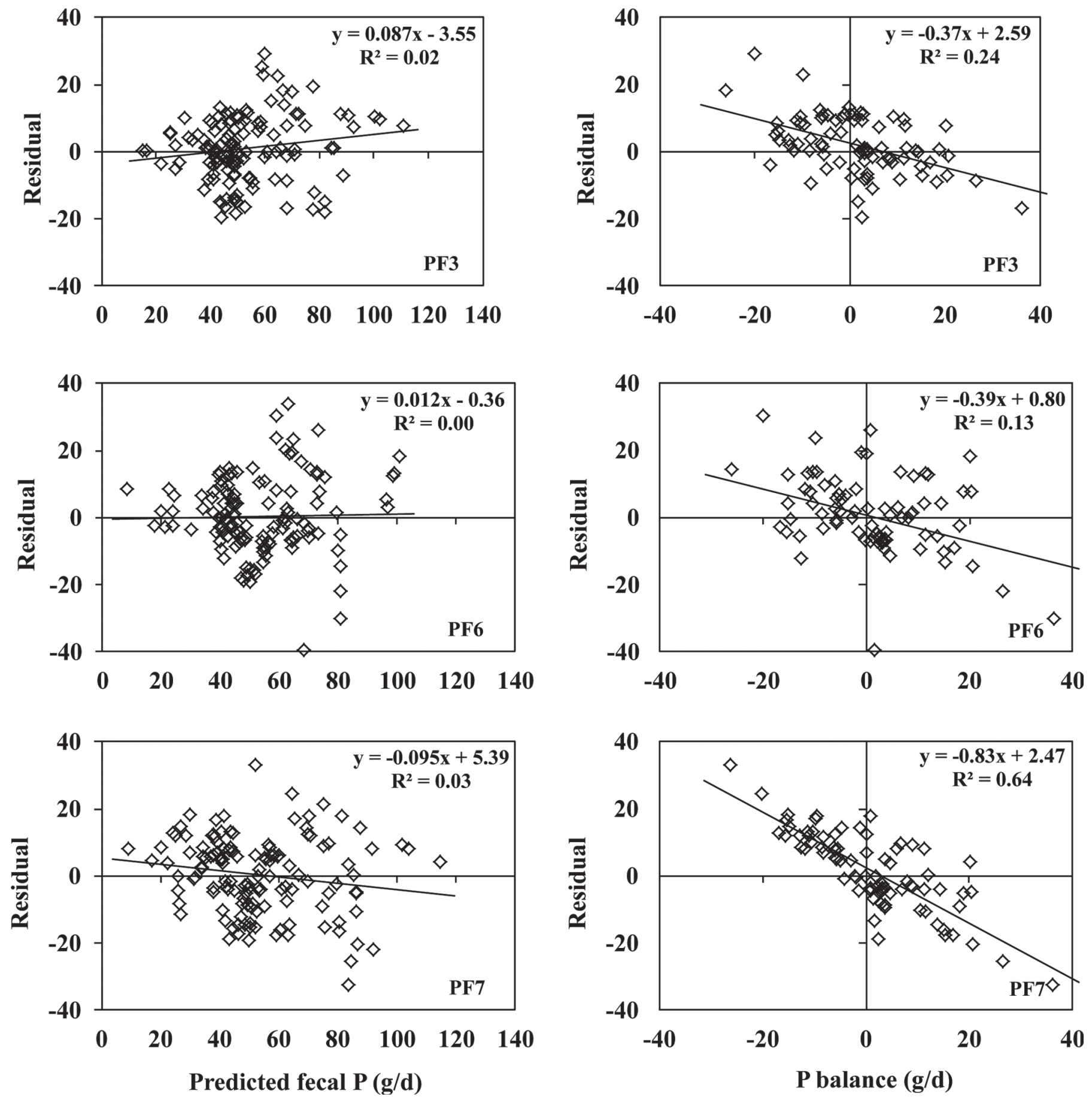

Figure 1. Left: Predicted values versus residual (observed - predicted) plots for equations PF3 [independent variable: P intake (g/d)], PF6 [independent variables: DMI ( $\mathrm{kg} / \mathrm{d}), \mathrm{P}(\mathrm{g} / \mathrm{kg} \mathrm{DM}), \mathrm{CP}(\mathrm{g} / \mathrm{kg}$ of DM), NDF (g/kg of DM)], and PF7 [independent variables: P intake (g/d), milk yield (kg/d)]. Right: Available P balance data ( $=81 ; 14$ studies) versus residuals (observed - predicted) for equations PF3, PF6, and PF7.

slope parameters were significant, but CCC and BIC did not improve despite an improvement in RMSPE. In general, none of the derived prediction equations for fecal $\mathrm{P}$ ( $\mathrm{g} / \mathrm{g}$ of intake) explained substantial amounts of observed variation, as $\mathrm{CCC}$ values were all $<0.30$
(Table 4). Large residuals were observed for some treatments with high dietary $\mathrm{P}$ concentrations (Morse et al., 1992; Kamiya et al., 2006a), which may be the result of lower P efficiency of absorption at high levels of dietary P. Similar to some of the prediction models for fecal P 
in grams per day, evaluation of the residuals shows that $\mathrm{P}$ balance appears to be a confounding factor (data not shown). The slope of the residuals when plotted against the predicted values was also significantly different from zero. If fecal $\mathrm{P}$ excretion is higher in a situation of negative $\mathrm{P}$ balance, it will logically comprise a larger fraction of $\mathrm{P}$ intake. Better understanding of the effect of $\mathrm{P}$ mobilization from body reserves, and its possible interactions with nutritional factors, on total $\mathrm{P}$ use efficiency is required to improve the quality of these prediction models if they are not only used for whole-farm situations.

\section{Milk P}

Milk $\boldsymbol{P}(\mathrm{g} / \mathrm{kg})$. Phosphorus required for milk production comprises a major fraction of the total $\mathrm{P}$ requirements of a modern dairy cow (NRC, 2001). However, the recommendations in different countries for $\mathrm{P}$ requirements differ substantially. For example, the $\mathrm{P}$ requirement according to various feed evaluation systems of a $600-\mathrm{kg}$ nonpregnant cow producing $30 \mathrm{~kg}$ of milk/d varies between 59 and $85 \mathrm{~g} / \mathrm{d}$ (Valk et al., 2000). The average milk $P$ concentration in our data subset was $0.89 \mathrm{~g}$ of $\mathrm{P} / \mathrm{kg}$ of milk (Table 2), which is very close to the constant value of $0.9 \mathrm{~g}$ of $\mathrm{P} / \mathrm{kg}$ of milk adopted in the NRC (2001) system. Variation in $\mathrm{P}$ concentrations in milk across studies may result partly from analytical error. Nevertheless, the range of values in our data subset (0.66 to $1.10 \mathrm{~g}$ of $\mathrm{P} / \mathrm{kg}$ of milk) shows that the $\mathrm{P}$ content of milk may actually vary considerably. Investigating factors that affect the $\mathrm{P}$ content of milk was therefore of interest, because variation in milk $\mathrm{P}$ content may have substantial effects on efficiency of $\mathrm{P}$ use for milk production (Bannink et al., 2010).

No significant effects of DMI, dietary P ( $\mathrm{g} / \mathrm{kg}$ of DM), or total $\mathrm{P}$ intake on the $\mathrm{P}$ content of milk were found. The effect of milk yield was also not significant, but inclusion of FCM or FPCM as a variable in the model did result in small, significant parameter estimates for these 2 potential driving variables (PM1, PM2). The significant effect of corrected milk yield on milk $\mathrm{P}$ content, where the uncorrected value is not significant, is most likely a result of the significant effects of milk protein percentage and milk fat percentage on milk $\mathrm{P}$ content (Table 5). An empirical relationship between the concentration of milk protein and the concentration of milk P has been reported previously (Lenstrup, 1926; Wu et al., 2000). Besides milk protein, milk lactose content can also affect the $\mathrm{P}$ content of milk (Shennan and Peaker, 2000), because inorganic $\mathbf{P}(\mathbf{P i})$ is generated during the formation of lactose in the Golgi apparatus, which can subsequently be secreted into milk together

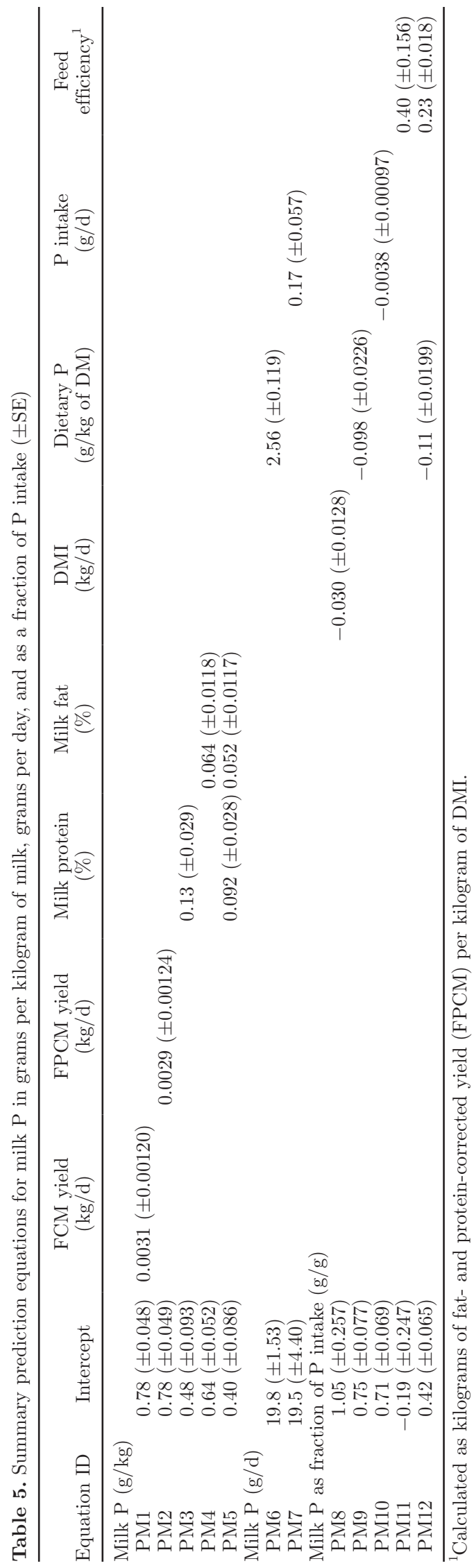


with other milk constituents. However, information on the lactose content of milk was not sufficiently available in our database to test this relationship. Equation PM3 (milk protein percentage) had the lowest RMSPE and highest CCC value. Addition of fat percentage to the equation (PM5) did result in a lower $\mathrm{BIC}$ value, but did not increase RMSPE or CCC, indicating no effect or a small additional effect of fat percentage on predicting milk $\mathrm{P}$ content. The CCC of the various equations to predict milk $\mathrm{P}$ content did not exceed 0.24 , which indicates that the overall predictive value of the linear models for milk $\mathrm{P}$ content derived in this study is low (Table 6). No clear patterns in the residuals (observed predicted) for the top performing equations were found, however (Figure 2). The 3 data points representing the largest residuals in both equation PM4 (milk fat percentage) and PM5 (milk protein percentage and milk fat percentage) are from the study by Peterson et al. (2005), where cows produced milk that was high in fat but low in P. Exclusion of this study from the analysis did not significantly alter the parameter estimates of the regression equations for milk $\mathrm{P}$ content, but largely removed any apparent slope from the residual plots.

Milk $\boldsymbol{P}(\mathrm{g} / \mathrm{d})$. For prediction of milk $\mathrm{P}$ in grams per day, significant parameter estimates were found for both dietary $\mathrm{P}(\mathrm{g} / \mathrm{kg}$ of $\mathrm{DM}$; PM6) and total $\mathrm{P}$ intake (g/d; PM7; Table 5). Based on RMSPE, CCC, and $\mathrm{BIC}$, the equation with $\mathrm{P}$ intake was better than that with dietary $\mathrm{P}$ content (Table 6$)$. Milk $\mathrm{P}(\mathrm{g} / \mathrm{d})$ is inherently related to milk yield, and most likely milk yield will be higher at higher intake levels, which may explain this result. The effect of DMI alone was not significant, but a tendency for an effect was observed $(P<0.10)$.

Milk $P$ as a Fraction of $P$ Intake $(g / g)$. Significant effects of dietary P (g/kg of DM; PM9), DMI (PM8), total P intake (g/d; PM10), and feed efficiency (PM11) were found for models of predicted milk $\mathrm{P}$ as a fraction of $\mathrm{P}$ intake (Table 5). The effects of milk yield, FCM, or FPCM were not significant. Feed efficiency and dietary P content (PM12) explained most of the variation in the observed data, but about onethird of the RMSPE of this equation is attributable to nonrandom error (Table 6). However, these terms may also be inherently related, as P efficiency ( $\mathrm{g}$ of milk $\mathrm{P} / \mathrm{g}$ of $\mathrm{P}$ intake) is nested within feed efficiency ( $\mathrm{g}$ of FPCM/g of DMI). Nevertheless, feed efficiency is often measured and, if related to $\mathrm{P}$ efficiency, could be useful as a prediction variable. Early lactation cows were used in the studies by Kamiya et al. (2006b) and Peterson

Table 6. Evaluation of prediction equations for milk $\mathrm{P}$ in grams per kilogram of milk, grams per day, and as a fraction of $\mathrm{P}$ intake

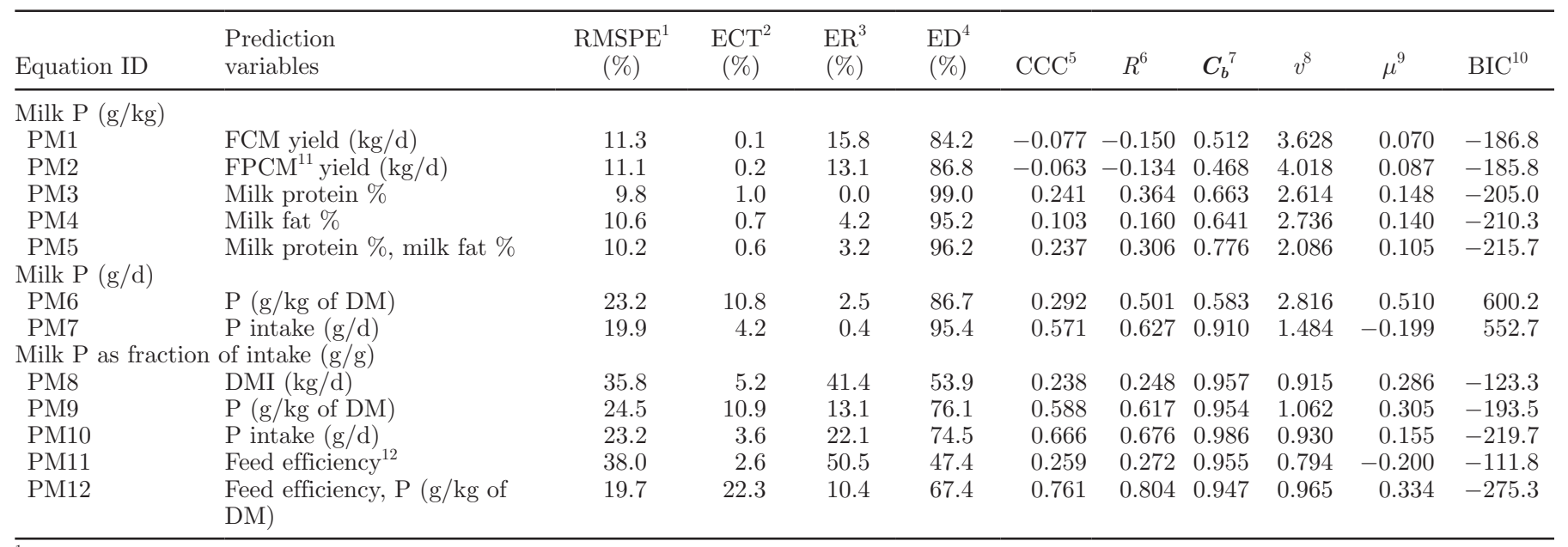

\footnotetext{
${ }^{1}$ Root mean square prediction error expressed as a percentage of the observed mean.

${ }^{2}$ Error resulting from overall bias, as a percentage of total mean square prediction error (MSPE).

${ }^{3}$ Error resulting from deviation of the regression slope from unity, as a percentage of total MSPE.

${ }^{4}$ Random error, as a percentage of total MSPE.

${ }^{5}$ Concordance correlation coefficient, where $\mathrm{CCC}=R \times C_{b}$.

${ }^{6}$ Pearson correlation coefficient.

${ }^{7}$ Bias correction factor.

${ }^{8}$ Scale shift.

${ }^{9}$ Location shift.

${ }^{10}$ Bayesian information criterion. Indicates goodness of model fit.

${ }^{11}$ Fat- and protein-corrected milk.

${ }^{12}$ Calculated as kilograms of FPCM yield per kilogram of DMI.
} 


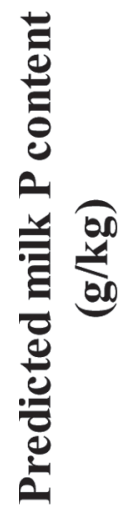

0.60
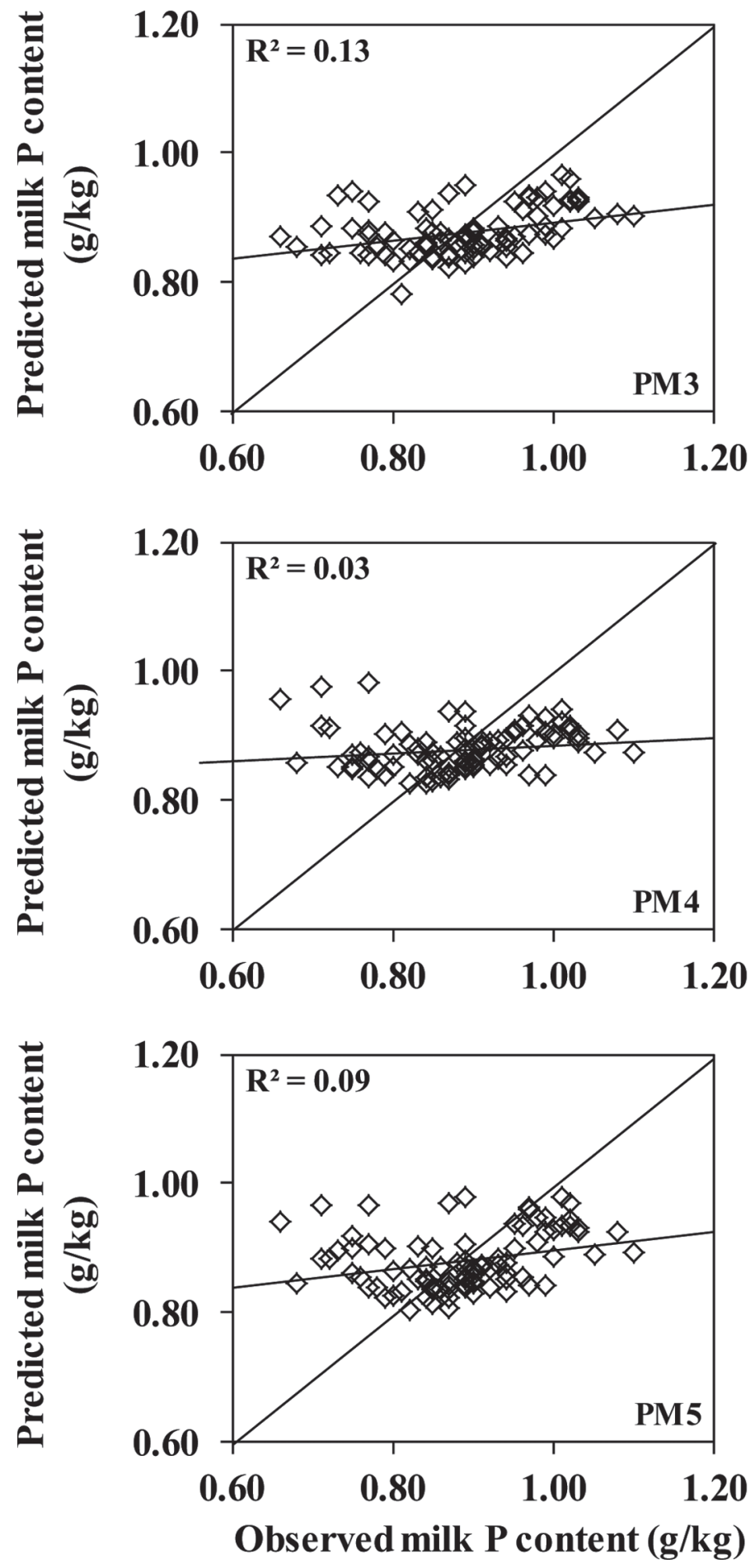
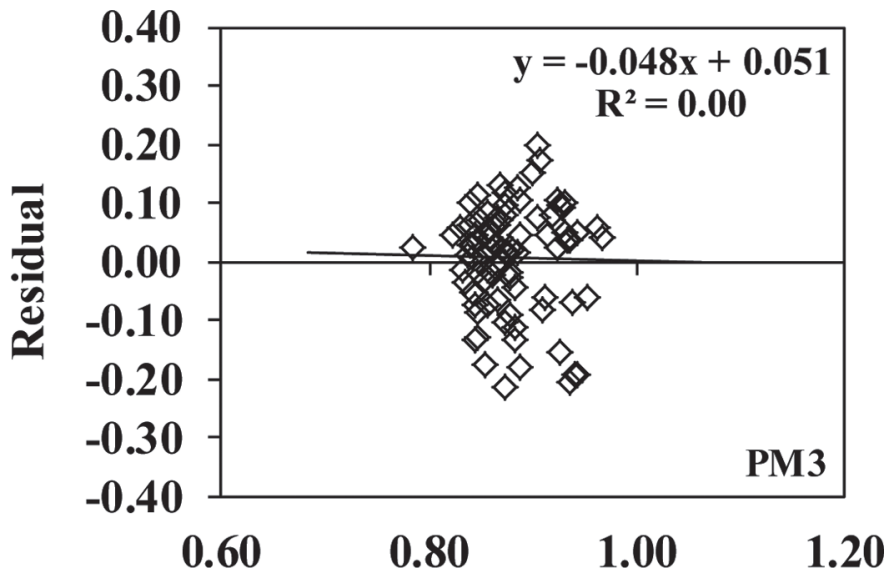

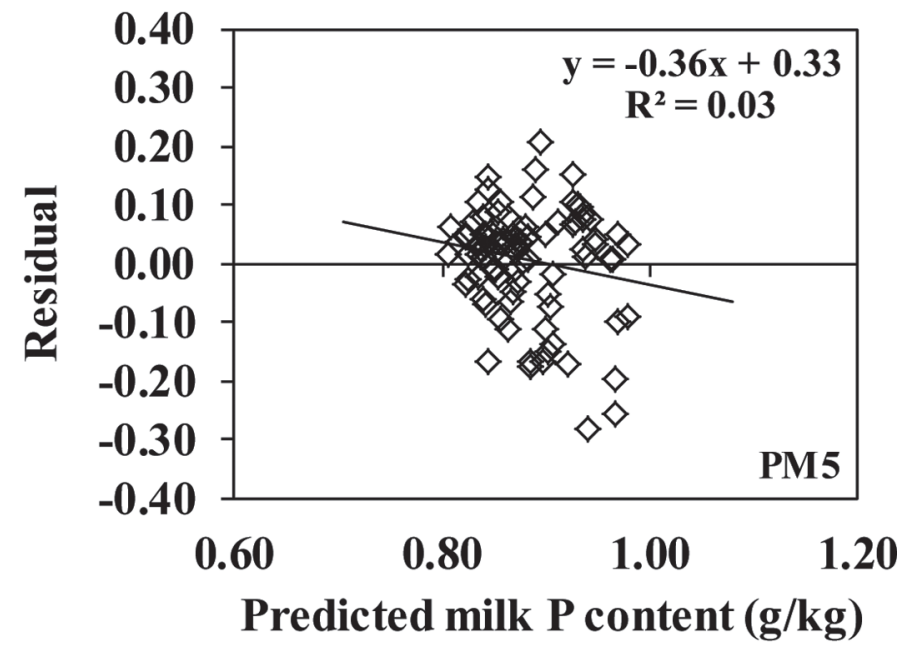

Figure 2. Observed versus predicted values for milk P content (left) and predicted values versus residuals (observed - predicted) (right) for equations PM3 (independent variable: milk protein \%), PM4 (independent variable: milk fat \%), and PM5 (independent variables: milk protein $\%$ and milk fat $\%)$.

et al. (2005), and high calculated feed efficiency values $(>2.5)$ likely indicate utilization of body reserves for milk production. Consequently, number of days in milk may have been a confounding factor, but this could not be tested based on information available in the current database. 


\section{Recommendations for Further Research}

Meta-analysis is a valuable tool to provide a quantitative summary of available data and to derive prediction equations for use in practice (St-Pierre, 2001). The statistical models derived in this study could be used to determine important factors affecting $\mathrm{P}$ use efficiency in dairy cows with the aim to incorporate these factors in a mechanistic model of $\mathrm{P}$ metabolism. Increasing interest in environmental issues has stimulated further development of nutrient-based mechanistic models within an environmental framework, and the need exists to include variation at the animal level in such nutrient-based mechanistic models (Dijkstra et al., 2007). In one extant mechanistic model of $\mathrm{P}$ metabolism in dairy cows (Hill et al., 2008), dietary $\mathrm{P}$ is the only dietary component included. The results of the present meta-analysis suggest that including effects of other nutritional factors, in particular dietary NDF and CP content, would benefit such a mechanistic model. Moreover, in the Hill et al. (2008) model, a constant concentration of Pi in milk was assumed. Comparing this with the study that contains the model input data (Knowlton et al., 2001) shows that the concentration of $\mathrm{Pi}$ in milk appears equal to the total $\mathrm{P}$ concentration in milk. This is unlikely, as part of the $\mathrm{P}$ in milk is complexed with casein (Lenstrup, 1926; Wu et al., 2001) and, as such, is not inorganic. Lenstrup (1926) and Forar et al. (1982) showed that of the various $\mathrm{P}$ fractions in milk, the Pi content is the most variable fraction throughout the year. It is not, however, clearly established whether this variation relates to season, diet composition, or lactation stage. Variation in milk $\mathrm{P}$ content is therefore also an aspect that should be considered for inclusion in future research efforts with regard to $\mathrm{P}$ metabolism in dairy cattle.

In this investigation, information on $\mathrm{P}$ balance and stage of lactation was not available for all treatments and therefore these variables as such could not be included as factors in the analysis. During early lactation, $\mathrm{Ca}$ is normally mobilized from bones to meet requirements for milk production. With the release of Ca from bone, $\mathrm{P}$ is also mobilized (NRC, 2001), which may have implications for the $\mathrm{P}$ requirements of early lactation dairy cows. Elizondo Salazar et al. (2012) estimated that a $600-\mathrm{kg}$ dairy cow may be able to mobilize up to $1,000 \mathrm{~g}$ of $\mathrm{P}$ from body reserves during the early lactation period. However, this is based on a suggestion about the possible extent of $\mathrm{P}$ mobilization in early lactation beef cattle (Ternouth, 1990). According to Taylor et al. (2009), cows may mobilize more than $1,000 \mathrm{~g}$ of $\mathrm{P}$ during the first $20 \mathrm{wk}$ of lactation, whereas deposition of $\mathrm{Ca}$ and resorption of $\mathrm{P}$ appeared to be unrelated. It was suggested by those authors that cows may be able to deposit $\mathrm{Ca}$ in bones in forms other than apatite salts. Contrasting results in the literature and the finding that $\mathrm{P}$ balance was a seemingly confounding factor in the current investigation underline the importance of better understanding and quantification of the prominent role of $\mathrm{P}$ resorption from bone and body tissues during early lactation in overall $\mathrm{P}$ metabolism.

\section{CONCLUSIONS}

Phosphorus excretion in feces was linearly related to $\mathrm{P}$ intake and explained most of the variation in the observed data. Significant effects of dietary CP and NDF and milk yield on fecal $\mathrm{P}$ excretion were also found. Results indicate that the $\mathrm{P}$ content of milk is influenced by milk composition, but that the observed variation could not be adequately described by any of the models derived in this study. Phosphorus in milk as a fraction of $\mathrm{P}$ intake was positively related to feed efficiency and negatively related to dietary $\mathrm{P}$ content. Present results can be used to determine relevant dietary and animal factors for inclusion in further research and modeling efforts with regard to $\mathrm{P}$ efficiency of dairy cows. In the present study, all available data were used for model development; therefore, further evaluation of the models against an independent database is recommended.

\section{ACKNOWLEDGMENTS}

The authors thank A. B. Strathe (Department of Basic Animal and Veterinary Sciences, University of Copenhagen, Copenhagen, Denmark) for statistical advice on the analysis of nonnormal data. Funding for this project was provided in part by the Canada Research Chairs Program (Ottawa, Ontario, Canada).

\section{REFERENCES}

Armentano, L., and M. Pereira. 1997. Measuring the effectiveness of fiber by animal response trials. J. Dairy Sci. 80:1416-1425.

Bannink, A., L. B. J. Sebek, and J. Dijkstra. 2010. Efficiency of phosphorus and calcium utilization in dairy cattle and implications for the environment. Pages 151-172 in Phosphorus and Calcium Utilization and Requirements in Farm Animals. D. M. M. S. Vitti and E. Kebreab, ed. CAB International, Wallingford, UK.

Bannink, A., M. W. van Schijndel, and J. Dijkstra. 2011. A model of enteric fermentation in dairy cows to estimate methane emission for the Dutch National Inventory Report using the IPCC Tier 3 approach. Anim. Feed Sci. Technol. 166-67:603-618.

Beever, D. E., and P. T. Doyle. 2007. Feed conversion efficiency as a key determinant of dairy herd performance: A review. Aust. J. Exp. Agric. 47:645-657.

Bibby, J., and H. Toutenburg. 1977. Prediction and Improved Estimation in Linear Models. John Wiley and Sons, London, UK.

Borucki Castro, S. I., L. E. Phillip, V. Girard, and A. Tremblay. 2004. Altering dietary cation-anion difference in lactating dairy cows to reduce phosphorus excretion to the environment. J. Dairy Sci. $87: 1751-1757$

Box, G. E. P., and D. R. Cox. 1964. An analysis of transformations. J. R. Stat. Soc. B 26:211-252. 
Bravo, D., D. Sauvant, C. Bogaert, and F. Meschy. 2003a. I. A bibliographic database for quantitative analysis of phosphorus flow in ruminants. Reprod. Nutr. Dev. 43:251-269.

Bravo, D., D. Sauvant, C. Bogaert, and F. Meschy. 2003b. II. Quantitative aspects of phosphorus absorption in ruminants. Reprod. Nutr. Dev. 43:271-284.

Bravo, D., D. Sauvant, C. Bogaert, and F. Meschy. 2003c. III. Quantitative aspects of phosphorus excretion in ruminants. Reprod. Nutr. Dev. 43:285-300.

Brintrup, R., T. Mooren, U. Meyer, H. Spiekers, and E. Pfeffer. 1993. Effects of 2 levels of phosphorus intake on performance and fecal phosphorus excretion of dairy cows. J. Anim. Physiol. Anim. Nutr. (Berl.) 69:29-36.

Cordell, D., J. O. Drangert, and S. White. 2009. The story of phosphorus: Global food security and food for thought. Glob. Environ. Change 19:292-305.

CVB. 2008. CVB Table Booklet Feeding of Ruminants. CVB series no. 43. Centraal Veevoederbureau, Lelystad, the Netherlands.

Dann, H. M., R. J. Grant, K. W. Cotanch, E. D. Thomas, C. S. Ballard, and R. Rice. 2008. Comparison of brown midrib sorghumsudangrass with corn silage on lactational performance and nutrient digestibility in Holstein dairy cows. J. Dairy Sci. 91:663-672.

Delaquis, A. M., and E. Block. 1995. The effects of changing ration ingredients on acid-base status, renal function, and macromineral metabolism. J. Dairy Sci. 78:2024-2039.

Dijkstra, J., J. L. Ellis, E. Kebreab, A. B. Strathe, S. López, J. France, and A. Bannink. 2012. Ruminal pH regulation and nutritional consequences of low pH. Anim. Feed Sci. Technol. 172:22-33.

Dijkstra, J., E. Kebreab, J. A. N. Mills, W. F. Pellikaan, S. Lopez, A. Bannink, and J. France. 2007. Predicting the profile of nutrients available for absorption: From nutrient requirement to animal response and environmental impact. Animal 1:99-111.

Dijkstra, J., O. Oenema, and A. Bannink. 2011. Dietary strategies to reducing $\mathrm{N}$ excretion from cattle: Implications for methane emissions. Curr. Opin. Environ. Sustain. 3:414-422.

Ekelund, A., R. Sporndly, and K. Holtenius. 2006. Influence of low phosphorus intake during early lactation on apparent digestibility of phosphorus and bone metabolism in dairy cows. Livest. Sci. 99:227-236.

Ekelund, A., R. Sporndly, H. Valk, and M. Murphy. 2005. Effects of varying monosodium phosphate intake on phosphorus excretion in dairy cows. Livest. Prod. Sci. 96:301-306.

Elizondo Salazar, J. A., J. D. Ferguson, D. B. Beegle, D. W. Remsburg, and Z. Wu. 2012. Body phosphorus mobilization and deposition during lactation in dairy cows. J. Anim. Physiol. Anim. Nutr. (Berl.) http://dx.doi.org/10.1111/j.1439-0396.2012.01291.x.

Ellis, J. L., A. Bannink, J. France, E. Kebreab, and J. Dijkstra. 2010. Evaluation of enteric methane prediction equations for dairy cows used in whole farm models. Glob. Change Biol. 16:3246-3256.

Ferris, C. P., M. A. McCoy, D. C. Patterson, and D. J. Kilpatrick. 2010. Effect of offering dairy cows diets differing in phosphorus concentration over four successive lactations: 2. Health, fertility, bone phosphorus reserves and nutrient utilisation. Animal 4:560-571.

Forar, F. L., R. L. Kincaid, R. L. Preston, and J. K. Hillers. 1982. Variation of inorganic phosphorus in blood plasma and milk of lactating cows. J. Dairy Sci. 65:760-763.

Guyton, A. D., J. M. McKinney, and K. F. Knowlton. 2003. The effect of steam-flaked or dry ground corn and supplemental phytic acid on phosphorus partitioning and ruminal phytase activity in lactating cows. J. Dairy Sci. 86:3972-3982.

Herrera, D., W. G. Harris, V. D. Nair, M. Josan, and C. R. Staples. 2010. Effect of dietary modifications of calcium and magnesium on reducing solubility of phosphorus in feces from lactating dairy cows. J. Dairy Sci. 93:2598-2611.

Hill, S. R., K. F. Knowlton, E. Kebreab, J. France, and M. D. Hanigan. 2008. A model of phosphorus digestion and metabolism in the lactating dairy cow. J. Dairy Sci. 91:2021-2032.

Kalscheur, K. F., J. H. Vandersall, R. A. Erdman, R. A. Kohn, and E. Russek-Cohen. 1999. Effects of dietary crude protein concentration and degradability on milk production responses of early, mid, and late lactation dairy cows. J. Dairy Sci. 82:545-554.

Kamiya, Y., M. Kamiya, and M. Tanaka. 2006a. The effect of prepartum diet on nitrogen and major mineral balance of dairy cows during parturition in summer. Asian-australas. J. Anim. Sci. 19:1415-1421.

Kamiya, Y., M. Kamiya, and M. Tanaka. 2006b. Effects of forage-toconcentrate ratio in prepartum diet on the dry matter intake and milk yield of periparturient cows during hot weather. Anim. Sci. J. $77: 63-70$.

Kebreab, E., J. France, J. D. Sutton, L. A. Crompton, and D. E. Beever. 2005. Effect of energy and protein supplementation on phosphorus utilization in lactating dairy cows. J. Anim. Feed Sci. 14:63-77.

Khorasani, G. R., R. A. Janzen, W. B. McGill, and J. J. Kennelly. 1997. Site and extent of mineral absorption in lactating cows fed whole-crop cereal grain silage or alfalfa silage. J. Anim. Sci. 75:239-248.

Kincaid, R. L., D. K. Garikipati, T. D. Nennich, and J. H. Harrison. 2005. Effect of grain source and exogenous phytase on phosphorus digestibility in dairy cows. J. Dairy Sci. 88:2893-2902.

Knowlton, K. F., and J. H. Herbein. 2002. Phosphorus partitioning during early lactation in dairy cows fed diets varying in phosphorus content. J. Dairy Sci. 85:1227-1236.

Knowlton, K. F., J. H. Herbein, M. A. Meister-Weisbarth, and W. A. Wark. 2001. Nitrogen and phosphorus partitioning in lactating Holstein cows fed different sources of dietary protein and phosphorus. J. Dairy Sci. 84:1210-1217.

Knowlton, K. F., J. M. McKinney, and C. Cobb. 2002. Effect of a direct-fed fibrolytic enzyme formulation on nutrient intake, partitioning, and excretion in early and late lactation Holstein cows. J. Dairy Sci. 85:3328-3335.

Knowlton, K. F., M. S. Taylor, S. R. Hill, C. Cobb, and K. F. Wilson. 2007. Manure nutrient excretion by lactating cows fed exogenous phytase and cellulase. J. Dairy Sci. 90:4356-4360.

Law, R. A., F. J. Young, D. C. Patterson, D. J. Kilpatrick, A. R. G. Wylie, and C. S. Mayne. 2009. Effect of dietary protein content on animal production and blood metabolites of dairy cows during lactation. J. Dairy Sci. 92:1001-1012.

Lenstrup, E. 1926. The phosphorus content of human milk and cows milk. J. Biol. Chem. 70:193-202.

Lin, L. I. 1989. A concordance correlation coefficient to evaluate reproducibility. Biometrics 45:255-268.

Martz, F. A., A. T. Belo, M. F. Weiss, R. L. Belyea, and J. P. Goff. 1990. True absorption of calcium and phosphorus from alfalfa and corn-silage when fed to lactating cows. J. Dairy Sci. 73:1288-1295.

Moreira, V. R., L. K. Zeringue, C. C. Williams, C. Leonardi, and M. E. McCormick. 2009. Influence of calcium and phosphorus feeding on markers of bone metabolism in transition cows. J. Dairy Sci 92:5189-5198.

Morse, D., H. H. Head, C. J. Wilcox, H. H. Vanhorn, C. D. Hissem, and B. Harris. 1992. Effects of concentration of dietary phosphorus on amount and route of excretion. J. Dairy Sci. 75:3039-3049.

Myers, Z. H., and D. K. Beede. 2009. Evaluating estimates of phosphorus maintenance requirement of lactating Holstein cows with different dry matter intakes. J. Dairy Sci. 92:708-719.

Nennich, T. D., J. H. Harrison, L. M. VanWieringen, D. Meyer, A. J. Heinrichs, W. P. Weiss, N. R. St-Pierre, R. L. Kincaid, D. L. Davidson, and E. Block. 2005. Prediction of manure and nutrient excretion from dairy cattle. J. Dairy Sci. 88:3721-3733.

NRC. 2001. Nutrient Requirements of Dairy Cattle. 7th rev. ed. Natl Acad. Sci., Washington, DC.

Odongo, N. E., D. McKnight, A. KoekKoek, J. W. Fisher, F. Sharpe, E. Kebreab, J. France, and B. W. McBride. 2007. Long-term effects of feeding diets without mineral phosphorus supplementation on the performance and phosphorus excretion in high-yielding dairy cows. Can. J. Anim. Sci. 87:639-646.

Peterson, A. B., M. W. Orth, J. P. Goff, and D. K. Beede. 2005 Periparturient responses of multiparous Holstein cows fed different dietary phosphorus concentrations prepartum. J. Dairy Sci 88:3582-3594. 
Puggaard, L., N. B. Kristensen, and J. Sehested. 2011. Effect of decreasing dietary phosphorus supply on net recycling of inorganic phosphate in lactating dairy cows. J. Dairy Sci. 94:1420-1429.

Roche, J. R., S. Petch, and J. K. Kay. 2005. Manipulating the dietary cation-anion difference via drenching to early-lactation dairy cows grazing pasture. J. Dairy Sci. 88:264-276.

Sauvant, D., P. Schmidely, J. J. Daudin, and N. R. St-Pierre. 2008. Meta-analyses of experimental data in animal nutrition. Animal $2: 1203-1214$

Shennan, D. B., and M. Peaker. 2000. Transport of milk constituents by the mammary gland. Physiol. Rev. 80:925-951.

Shore, K. V., N. E. Odongo, T. Mutsvangwa, T. M. Widowski, J. P. Cant, W. J. Bettger, and B. W. McBride. 2005. Phosphorus status of lactating dairy cows fed total mixed rations containing $0.24 \%$ vs. $0.36 \%$ phosphorus. Can. J. Anim. Sci. 85:409-412.

Spiekers, H., R. Brintrup, M. Balmelli, and E. Pfeffer. 1993. Influence of dry matter intake on fecal phosphorus losses in dairy cows fed rations low in phosphorus. J. Anim. Physiol. Anim. Nutr. (Berl.) 69:37-43.

St-Pierre, N. R. 2001. Invited review: Integrating quantitative findings from multiple studies using mixed model methodology. J. Dairy Sci. 84:741-755.

Taylor, M. S., K. F. Knowlton, M. L. McGilliard, W. S. Swecker, J. D. Ferguson, Z. Wu, and M. D. Hanigan. 2009. Dietary calcium has little effect on mineral balance and bone mineral metabolism through twenty weeks of lactation in Holstein cows. J. Dairy Sci. 92:223-237.

Ternouth, J. H. 1990. Phosphorus and beef-production in Northern Australia 3: Phosphorus in cattle-A review. Trop. Grassl. 24:159-169.
Valk, H., J. A. Metcalf, and P. J. A. Withers. 2000. Prospects for minimizing phosphorus excretion in ruminants by dietary manipulation. J. Environ. Qual. 29:28-36.

Valk, H., L. B. J. Sebek, and A. C. Beynen. 2002. Influence of phosphorus intake on excretion and blood plasma and saliva concentrations of phosphorus in dairy cows. J. Dairy Sci. 85:2642-2649.

Van Straalen, W. M., I. Kok, and B. M. Tas. 2009. De invloed van gerichte verlaging van de $\mathrm{P}$-opname en structuurvoorziening op voeropname, melkproductie, vertering van rantsoencomponenten en P status van melkkoeien (In Dutch). Shothorst Feed Research, Lelystad, the Netherlands.

Weiss, W. P., and D. J. Wyatt. 2004. Macromineral digestion by lactating dairy cows: Estimating phosphorus excretion via manure. J. Dairy Sci. 87:2158-2166.

$\mathrm{Wu}, \mathrm{Z} .2005$. Utilization of phosphorus in lactating cows fed varying amounts of phosphorus and sources of fiber. J. Dairy Sci. $88: 2850-2859$.

Wu, Z., L. D. Satter, A. J. Blohowiak, R. H. Stauffacher, and J. H. Wilson. 2001. Milk production, estimated phosphorus excretion, and bone characteristics of dairy cows fed different amounts of phosphorus for two or three years. J. Dairy Sci. 84:1738-1748.

Wu, Z., L. D. Satter, and R. Sojo. 2000. Milk production, reproductive performance, and fecal excretion of phosphorus by dairy cows fed three amounts of phosphorus. J. Dairy Sci. 83:1028-1041.

Wu, Z., S. K. Tallam, V. A. Ishler, and D. D. Archibald. 2003. Utilization of phosphorus in lactating cows fed varying amounts of phosphorus and forage. J. Dairy Sci. 86:3300-3308. 